tial targeting is not expected to emerge in final NSF legislation.

\section{Rick K. Wilson to Join NSF as Political Science Rotator}

Rick K. Wilson is joining the political science program in the Division of Social, Behavioral, and Economic Research at the National Science Foundation on an annual assignment on leave from Rice University. Wilson, professor in the political science department at Rice, and formerly its chair, is a specialist in legislative politics, research methods, social choice and game theory, and normative democratic theory. He is the author, with Cal Jillson, of Congressional Dynamics: Structure, Coordination and Choice in the First American Congress, 1774-1789 (Stanford University Press, 1994.)

The political science program at NSF supports social scientific research to improve the understanding of politics, political behavior, and political institutions and processes. Recent research sponsored by the program includes studies of activists in American political parties, information and issues in voting, support for political institutions, and the process of democratization. Rotators, in collaboration with the program director, Frank Scioli, support the proposal review process and help disseminate information to prospective principal investigators about NSF-funded research opportunities. The rotator position was last filled by John McIver, on leave from the University of Colorado at Boulder.

\title{
Index of APSA Reports in PS, September 1995-June 1996
}

Article

American Political Science Review

APSR's Book Review, 1991-95

Report of the Managing Editor of the American Political Science Review, 1994-95

Annual Meeting 1995

The Windy City Favors the 1995 Annual Meeting

Large Audiences Drawn to 1995 Panels

Awards

APSA Awards Presented at 1995 Annual Meeting

Committees

Report on the Status of Lesbian and Gays in the Political Science Profession

APSA Committees

Congressional Fellowship Program

CFP Announces 1995-96 Competition Winners

43rd Class of Congressional Fellows Begins 1995-96 Program

Report on the Congressional Fellowship Program

Norman Ornstein to Head CFP Advisory Committee

Council

APSA Council Minutes

APSA Council Minutes, August 1995

Dissertations

Doctoral Dissertations in Political Science, 1994

Executive Director

Report of the Executive Director

Gopher/Internet Report

APSA Gopher Report

APSA Internet Report

Governing Rules

APSA Constitution and Bylaws

Annual Meeting Business Rules

Organized Sections

Section News

Update on Organized Sections

Section News

Section News

Presidents and Officers

Arend Lijphart: A Profile

Treasurer's Report

Kent Jennings Nominated President-Elect

Profession

Ranking Research Doctorate Programs in Political Science

Two-Year College Political Science Faculty: Recruitment and Responsibilities

Job Prospects for Political Scientists: Placement Experience in 1995

Professional Development

Annual Meeting Short Courses Provide Diverse Professional Development Opportunities

1996 Annual Meeting Short Courses

\section{PS Reports}

Index of APSA Reports in PS

Index of Authored Articles

Publications

Publications List

Publications List

Publications List

Publications List

National, Regional, and State Association News

Listing of Regional and State Political Science Associations

Research Support

1995 Research Support Grants Announced

Women and Minorities

1995 Ralph Bunche Summer Institute

Participation by Women in the 1995 Annual Meeting

1996 APSA Minority Fellows

UVA and Paley Foundation Support Bunche Summer Institute
Issue

Page

September 1995

December 1995

December 1995

December 1995

December 1995

September 1995

March 1996

September 1995

December 1995

March 1996

June 1996

September 1995

December 1995

December 1995

September 1995

December 1995

March 1996

June 1996

June 1996

December 1995 December 1995

March 1996

June 1996

December 1995

December 1995

June 1996

December 1995

March 1996

June 1996

December 1995

June 1996

September 1995

September 1995

December 1995

June 1996

March 1996

0

